\title{
A Process Re-Conceptualization of Entrepreneurial Orientation Aimed at Opportunity Designing
}

\author{
Alberto Francesconi \\ Associate Professor of Business Organization \\ Department of Economics and Management \\ University of Pavia \\ San Felice al Monastero 5, Pavia 27100 \\ Italy
}

\begin{abstract}
The recognition or the creation of opportunities is the starting points of any entrepreneurial project and Entrepreneurial Orientation is considered to beat the core. The traditional use of Entrepreneurial Orientation has been focused on explanations, such as those within natural science, combined with a conception of entrepreneurs as possessing exceptional traits, as heroic individuals: these perspectives are incorrect. This study proposes a critical process re-conceptualization of Entrepreneurial Orientation aimed at opportunity designing in uncertain contexts as well as (proto) organizational projects. The major contribution is a theoretical framework under a process perspective that brings together research fields that have been isolated for too long, focusing on the interplay between routines and artifacts (as rules), agency and structure, sense-making and decision-making. Using our framework, scholars may explore further entrepreneuring and organizing, unifying a highly disparate research domain centered on opportunity designing.
\end{abstract}

Keywords: Entrepreneurial Orientation, Process View, Opportunity Designing, Sense-making, Decision-making, Designing, Routines, Artifacts

\subsection{Introduction and purpose of the work}

Entrepreneurial Orientation is considered to beat the core of the entire entrepreneurial process (Katz and Gartner, 1988; Krueger and Carsrud, 1993) for both the foundation and the growth of a new opportunity. Indeed, Miller (1983) has suggested that entrepreneurial firms are those that pursue innovation, aggressively enter new markets, and accept a measure of strategic and financial risk in the pursuit of new opportunities. Lumpkin and Dess (1996) defined Entrepreneurial Orientation as a 'firm's strategic orientation, capturing specific entrepreneurial aspects of decision-making styles, methods, and practices. As such, it reflects how a firm operates rather than what it does. It is a multidimensional construct in which risk-taking, innovativeness, proactiveness, competitive aggressiveness, and autonomy are treated as independent behavioral dimensions [...][Entrepreneurial Orientation is] defined as new entry. That is, new entry explains what entrepreneurship consists of, and EO describes how new entry is undertaken. The essential act of entrepreneurship is new entry' (p. 136).

Entrepreneurial Orientation is necessarily linked to new entry as a central idea: they are inseparable constructs in a practical sense (Covin and Miller, 2014:6). New entry can consist of entering new or established markets offering new or existing goods or services, as well as the act of launching a brand-new venture, either by a start-up, through an existing firm, or via 'internal corporate venturing' (Burgelman, 1983).

The main activity of an entrepreneur is to turn an idea into a full-time business (Trimi and Berbegal-Mirabent, 2012); one that enters or creates a new market or changes the rules of the game, dealing with organizational and managerial learning challenges. Launching a new venture extends the action of the entrepreneur - often a collective - beyond the development of goods or service concepts, including the action streams of designing and organizing, to actually developing a business opportunity (George and Bock, 2011:99).

An interesting point of convergence between entrepreneurship and organizational studies is provided by the fact that a process perspective is well suited for both. As argued by Hjorth et al. (2015) 'process studies put movement, change and flow first; to study processually is to consider the world as restless, something underway, becoming and perishing, without end.' [...] the resonance with entrepreneurial studies is obvious. If any field is alive to and fully resonant with a processual understanding of what we have labelled 'the firm', it is entrepreneurship. [...] appreciating entrepreneurial phenomena processually opens up the field to an understanding of entrepreneurship as organizational creation - not simply the creation of new organizations, but experiments in new organizational form and different purposes which make sense of the experience of being organized' (p. 599). 
In the entrepreneurship field, several scholars argue that the study of process is at the core of entrepreneurship (Acs and Audretsch, 2010; Moroz and Hindle, 2012). Cope (2005) re-framed entrepreneurship as the 'contextual process of "becoming" where the entrepreneur is continually learning and developing in relation to his/her business and the wider environment' (p. 374). A process orientation offers a wealth of unexplored potential to understand, and perhaps unify, a very heterogeneous research domain (Bygrave, 2007; Low and MacMillan, 1988; Ucbasaran et al., 2001; Zahra, 2007), and conceives entrepreneuring as the ongoing creative organizing that materializes a new venture (Verduyin, 2015:639). This also implies the disruption of a status quo (Goss et al., 2011; Johannisson, 2011) and alters daily practices (Hjorth and Steyaert, 2004), interrupting 'the continuity of the normal, clearing space for the new to emerge' (Hjorth, 2013:46). With a focus on creating (Steyaert, 2007), entrepreneuring becomes a dynamic social phenomenon, i.e. a proactive intervention within the flux of everyday life.

In the organizational field some scholars argue that organizations are action streams (e.g. Starbuck, 2003), action nets (Czarniawska, 2004), (much) 'more than structure' (Jelinek et al., 2008:319); fundamentally a process (Hernes, 2014).

As argued by Dunbar and Starbuck (2006) and Jelinek et al. (2008), a promising focus for organizational studies relies on a science for design, inspired by Simon's (1969) work, The Sciences of the Artificial (Jelinek et al., 2008): 'while the natural sciences seek description, explanation or prediction of what is, design scientists ask what could be, seeking betterment of the human condition [...] According to Simon (1969), science views existing organizational systems as empirical objects from an outsider perspective, while design envisions systems that do not yet exist - either completely new systems or new states of existing systems. Science raises the question "is this proposition valid or true?", while design asks, "will it work better?" [...].The very word "organization" may itself be part of the problem, signaling a fictitious permanence, and emphasizing success. Design instead implies a dynamic process leading to impermanent outcomes, and iterative engagements with designing and organizing that embrace ephemerality and constant improvement (Weick 1979; Yoo et al. 2006)' (p. 319).

Design is important for entrepreneurship because it offers ways of thinking that make entrepreneurs able to face and solve complex problems in new and original ways, discovering or creating new opportunities (Nielsen et al., 2017). Breaks for new entrepreneurial opportunities occur through an iterative interaction between processes, in which the past and the present are perceived, enacted and re-framed, ideas for the future are shaped, and different representations, solutions and opportunity spaces are selected, combined, tested and experimented with. The entrepreneurial process is, therefore, a continuous process of re-design, consistent with other process perspectives in the field of organization studies, which emphasize iterations and constant changes.

Unfortunately, the traditional conceptof Entrepreneurial Orientation has been applied to provide mere explanations, such as those within natural science (Dunbar and Starbuck, 2006): 'in social science, striving for generality involving predictable relations between one variable and another is often inappropriate, for not only are the factors or processes important in one situation often different in the next, but also the situations themselves change as new circumstances emerge' (p. 177). In the case of new ventures, for example, entrepreneurs often move away from existing paths, modify the rules of the game, and constantly encounter experiences of transformation (Hjorth et al., 2015). Traditional entrepreneurship literature mainly attributes the success and failure of new ventures and opportunities to specific individuals (for an extensive review see Gartner, 1988) and some researchers have conceptualized entrepreneurs as possessing exceptional traits, as heroic individuals: these perspectives have been highly criticized in the literature.

Therefore, the purpose, structure and originality of this study relies on:

1) A re-conceptualization of Entrepreneurial Orientation as an iterative process, rather than a mere aptitude or a set of personal traits, focusing more on "How" an entrepreneur (individual or collective) acts, rather than the "What": i.e. a process oriented to designing new entrepreneurial opportunities.

2) The development of a framework in which structuration and agency, sense-making and decision-making are the theoretical backbones of Entrepreneurial Orientation, gravitating around the designing and organizing of new opportunities.

3) The potential role of convergence and dialogue allowed by our re-conceptualization and framework in the entrepreneurship, organization, learning and design fields.

\subsection{Limits of the traditional conception of Entrepreneurial Orientation}

With special reference to the core issue of Entrepreneurial Orientation, we noted that from trying to develop a better understanding of what Miller originally proposed, quantitative measurement has become an accepted explanation, too often reduced to "how much" of thisis present when gauging high performance and growth. 
For example, over time, many authors have tested the relationship between Entrepreneurial Orientation and firm performance with some counter-intuitive results (for a meta-analysis exploring the magnitude of the Entrepreneurial Orientation-performance relation see Rauch et al., 2009). As in the case of research that employs psychological traits, there is a strong practical appeal in a readily-measurable construct that seems to offer explanations forthe results, at the cost of losing a grasp of the nuances, interactions and dynamics (Anderson et al., 2012) which are typical of processes developed over time. Dissatisfied with this drift, we have deepened the literature on Entrepreneurial Orientation and found three main problems, although non-exhaustive, summarized as follows for the sake of brevity.

Firstly, notwithstanding the cumulative body of study on Entrepreneurial Orientation, several ontological questions persist (see for example Covin and Lumpkin, 2011; Covin and Wales, 2012; Garud, Karnøe, 2003; George and Marino, 2011; Lumpkin and Dess, 2001; Miller, 2011).

Secondly, the mainstream premise of the personality perspective is that some individuals possess a unique set of inherent and fixed personality traits that predispose them to entrepreneurial activity (Greenberger and Sexton, 1988). This search for the personality and traits - consistent across time and different contexts (Cope, 2005) - of successful entrepreneurs, compared with failed entrepreneurs and non-entrepreneurs, has received heavy criticism (Duening, 2010; Gartner, 1988; Garud and Karnøe, 2003; Sarasvathy, 2001). For example, in terms of riskattitude, Duening (2010) argues: 'a common (mis)perception often expressed is that entrepreneurs are notorious risk takers. [...] Of course, some entrepreneurs are risk takers to an extraordinary degree, but the frequency of risk taking among entrepreneurs is likely similar to that of the general population' (p. 12).

Thirdly, many studies see high Entrepreneurial Orientation as an advantage (Bhuian et al., 2005; Ireland et al., 2003; Kreiser, 2011; Wiklund and Shepherd, 2003). Only a few empirical studies focus on failure, e.g. Wiklund and Shepherd (2011) found that Entrepreneurial Orientation and high tolerance of risk have a positive relationship with relative performance among surviving firms. However, they have found that Entrepreneurial Orientation also has a positive relationship with firm failure. These critics argue that previous and mainstream studies, being focused only on successful firms, were not able to find that Entrepreneurial Orientation, and in particularly a high tolerance of risk, has a positive relationship with both firm failure and success. The authors conclude that 'the quantification of Entrepreneurial Orientation is not so conclusive' and that it is fundamentally a dynamic concept 'to be investigated as a process' with important feedback and learning effects (Wiklund and Shepherd, 2011:937).

\subsection{Ideas for a re-conceptualization of Entrepreneurial Orientation}

Within our tentative framework, we extend previous work by Chiasson and Saunders (2005), based principally on the Structuration Theory by Giddens $(1984 ; 1991)$, with the dissolution of the dichotomy between objective and subjective perspectives. Entrepreneurs who face high uncertainty and cannot rely on predictions about an unknowable future do not evaluate or assess existing opportunities, but actively create 'the alternative themselves' (Sarasvathy, 2003:207). Obviously, there are different methods, techniques, routines and physical or logical cognitive devices that can be used and (re-)adapted, in order to 'create' new opportunities in different contexts (e.g. in start-up ventures rather than large and established businesses, at an individual or a collective level, and so forth); an exhaustive analysis of these is far beyond the scope of this work. Design Thinking, proposed by Buchanan (1992) more than two decades ago, can be considered as an interesting example of method, 'an intellectual approach to problem-framing and solving that can be used whenever we are facing complex, ambiguous or undecidable situations' (Berti, 2013: 158), which is typical of entrepreneuring and organizing.

\subsection{Structuration Theory and Entrepreneurial Opportunities}

Structuration Theory suggests that people's actions create structure, and without action, structures disappear (Chiasson and Saunders, 2005:751). Structures, collectively created, open up many possibilities for agency: they represent a sort of memory capable of guiding actions, providing useful indications for facing uncertainty without requiring new research and information processing every time. When individuals act consistently within these structures, they strengthen and stabilize the structures. However, given that individuals are reflective and capable of conscious and voluntary actions, there is a possibility that these structures might not be respected. If many individuals start to follow different rules (e.g. inspired by charismatic entrepreneurs), the structures themselves may change. This view offers a very different approach fromthe traditional view of entrepreneurship as a filler of existing market gaps: on the contrary, the entrepreneur may be a 'rule-breaker' who triggers a structure's change, unleashing morphogenetic forces, convincing many individuals to follow different rules. 
For example, Garud and Karnøe (2003:277), focusing on technological entrepreneurship, argue that entrepreneurial agency is distributed across many actors, because the skills and resources required to take an idea from its inception to commercial use must be mobilized by drawing upon the generative impulses of actors from multiple domains. This indicates a greaterprocess that builds upon the efforts of many.

Moreover, the traditional view presents entrepreneurial ventures as being designed ex ante by heroic entrepreneurs guided by an Olympian rationality. On the contrary, Structuration Theory suggests that anentrepreneur (including collectives) and social systems co-evolve, presenting entrepreneurial ventures as recursive processes that evolve as the entrepreneur engages with different sources of opportunity and the venturing process. The entrepreneur's rationality remains intentional, but bounded, facing a complex and often unpredictable 'world'.

In work by Chiasson and Saunders (2005:751), the connection between structure and agency is made by repeatable human action observed in scripts (Barley and Tolbert, 1997), seen as behavioral grammars that inform everyday action (Barley, 1986). Even if scripts, thanks to imitation, mightenable quick and useful action in particular business and social structures, entrepreneurial power also arises from doing things (very) differently. Chiasson and Saunders (2005) argue that intentional and conscious change is addressedless in Structuration Theory, but that it is coherent with its concepts and themajor emphasis given to agency. As a result, script change may be 'deliberate and conscious individual play and experimentation with scripts to "see what happens", in combination with chance accidents' (Chiasson and Saunders, 2005:752).

In brief, in the Chiasson and Saunders (2005) model, entrepreneurial opportunity can be re-conceived as the selection, use or modification of structure-guided scripts. This is not so far from the processes of sense-making outlined by Weick (1979). Indeed, Giddens'Structuration Theory (1984) proposesa synthesis as a broader theoretical basis forsensemaking. As in sense-making, Structuration Theory takes as a given that the only place we can find something close to a social or organizational structure is in the relational interaction of the actions of human beings, who respond to other actions and anticipate others' reactions to their actions. Thus, we advance the Chiasson and Saunders model by strengthening the cognitive perspective: we adjust their model by concentrating, in the next section, on routines, rather than on scripts, and on artifacts, as both physical and logical tools (e.g. software and hardware, or methods). The cognitive perspective refers to the mental representations and processes aimed at human decision-making (Helfat and Martin, 2015). Sosna et al. (2010) argued that the cognition and sense-making of the entrepreneur provides 'the most important input into the initial business model design' (p. 386), seen as a "function" of the entrepreneur's interpretation of events (Kirzner, 1997). This idea has recently gained traction as 'an important key to understanding central aspects of entrepreneurship' (Baron, 2014:61).

\subsection{Decision-making and sense-making}

We consider the relationship between human decision-making, based primarily on the work of Simon (1957), and sense-making, based primarily on the work of Weick (1979, 1995), as suggested by Boland (2004:55), who highlights some of the difficulties in bringing the two processes together into a single framework.He thenproposedesigning as a possible way of achieving this. We build on these preliminary arguments to link Structuration Theory and Entrepreneurial Orientation in terms of entrepreneurial opportunity designing. Indeed, the type of rationality described by Simon (1957) introduces the logical moment of representation for action as a central element of the decision-making process, as a set of rules that link goals, states of the perceived world and actions to be undertaken. Here, routines and artifacts come into play more precisely.

In this work, we prefer the concept of routines rather than scripts as used by Chiasson and Saunders (2005), in the search for greater congruence with organizational action and the recent entrepreneurship research domain focused on new ventures and start-ups. Indeed, the concepts of scripts and routines seem similar, but they do not completely correspond. The concept of scripts derives from the behaviorist school, and this school when applied to routines shows relevant internal contradictions (see Zamarian, 2011). For example, understanding routines as sets of behaviors presupposes the impossibility of recognizing a routinized character in activities that manifest themselves, from time to time, in merely 'similar', not identical, behaviors, which is almost impossible to do over time or in different contexts (Zamarian, 2011). Furthermore, it is clearthat there is a continuous learning process that constantly refines routines, not only in an accidental or unconscious way: situations of total suspension of thought activity during the execution of routines must be considered extreme situations. Routines can be generated in an emergent and endogenous way and then made explicit through the abstraction of routinized practice: this happens in situations where routinized practices arise from a combination of rules discovered or shaped by agents. However, even if routines are deliberately designed in an exogenous way and explicitly, they function because they are always mediated by their interpretation and recontextualization by the individual, who maintains, in any case, a space of agency in the adoption of the rules. 
This is consistent with the routine literature review according to the "practice perspective" discussed by Parmigiani and Howard-Grenville (2011). They cite Reynaud (2005), who distinguishes rules, as arrangements awaiting interpretation, from routines, as rules already interpreted: routines provide pragmatic, local, and temporary solutions to the incompleteness of general rules and are worked out through interaction. According to Zamarian (2011), there are two ways in which routines and artifacts intervene in the core process of representation for action.

On the one hand, they are the result of an iterative decision and action process, i.e. they are a partial product. Only by deciding to act, in a contextualized way, can worthiness and success be assessed; this kind of contextualization and iteration is typical of designing and organizing. On the other hand, routines and artifacts are not only the result of iterations of decision and action but are also elements that agents include and consider within the decision-making process itself. Routines and artifacts, in other words, after being generated and adopted, become part of the definition of the situation and contribute to defining the decision context. These "tools", therefore, have effects on the structuration and on reducing environmental complexity. Thus, we argue, they also have an important role in the more specific domains of opportunity designing and organizing.

\subsection{Decision-making and sense-making: an interplay reconciliation}

A specific feature of the decision-making process is its future orientation (Figure 1). However, as raisedby Boland (2008), 'where do the alternatives that a decision maker chooses among come from in the first place if not from the engaged search for the conditions of betterment by an actor? And does not the act of deciding itself involve a continuous reshaping of the alternatives being considered?' (p. 59).

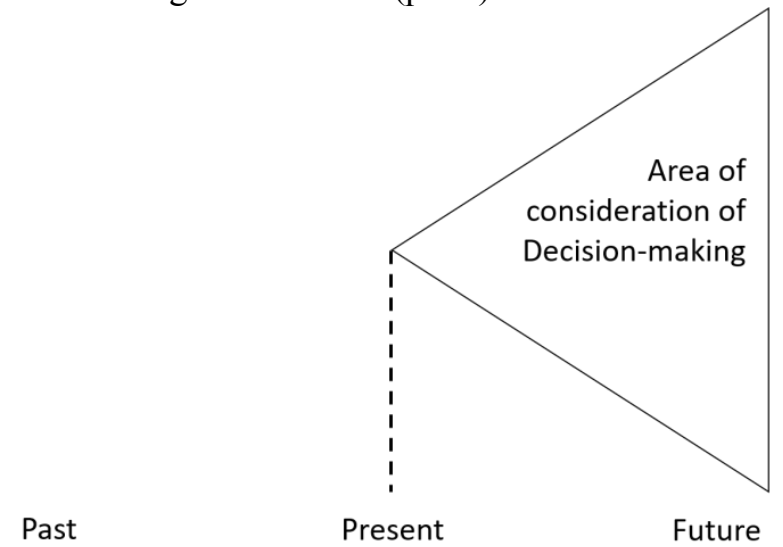

Figure 1. Decision-making and time (Adapted from Boland, 2004, p. 57).

As argued by Weick et al. (2005), 'explicit efforts at sense-making tend to occur when the current state of the world is perceived to be different from the expected one, or when there is no obvious way to engage the world' (p. 415). Even if the focus of theorizing for sense-making is based on the present, the temporal attention is toward the past. 'The sensemaking view begins with equivocal enactments - which can be conscious or not - that are encountered in the present moment and looks backward through time to attribute meaning to them and reduce their equivocality' (Boland, 2008:57-58). A distinguishing feature of sense-making includes its genesis in 'disruptive ambiguity' (Weick et al., 2005:415), which, in our opinion, is well-suited tocases of disruptive innovations, even when unleashed by the entrepreneur. Sense-making can be depicted as in Figure 2.

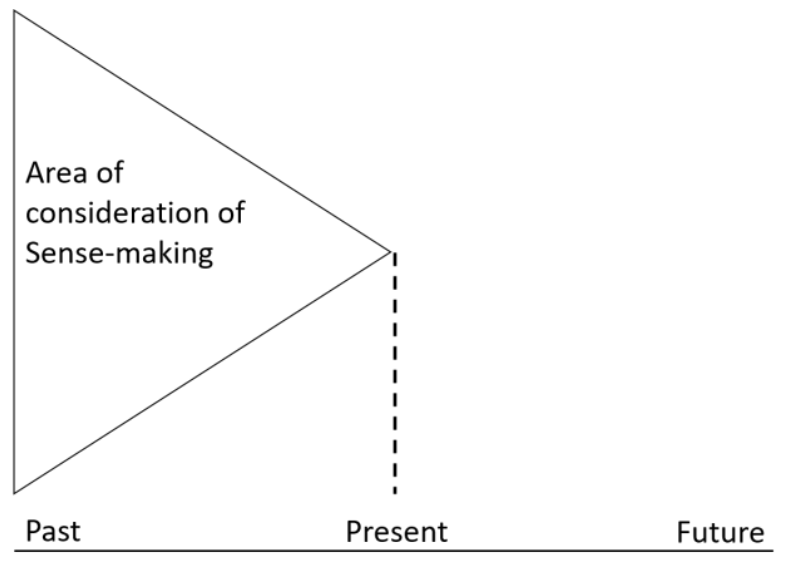


Figure 2. Sense-making and time (Adapted from Boland, 2004, p. 58).

In brief, the elements of the representation of the situation are not given, but are the result of sociological, behavioral and cognitive processes that include the actions of the decision-maker and of the subjects interacting with him/her.

A sense-making perspective emphasizes the potential equivocal meaning of the fresh trace of action we have just experienced. The problem for sense-making is understanding what we have just done in a contextualized way.This kind of contextualization and iteration is typical of designing (and organizing).

However, the fundamental issue is to understand that decision-making and sense-making cannot be integrated, but are intended only as alternated with iterations, within a higher-order or meta-level construct of designing. In any case, Herbert Simon (in his classic The Sciences of the Artificial, 1969), had already pointed to design as the human activity that brings the diverse, seemingly incommensurate aspects of an objective, analytical, decision-making discipline together with the subjective, form-giving aspects of sense-making.

Decision-making and sense-making can be used for studying human action together, 'not through an integration, but through the interplay within design science' (Boland, 2008:61). We propose aprocessual,iterative and dialectical interplay (Figure 3), inspired by dialectics, which is an important conceptual framework in organizational theory (e.g. Benson, 1977) and combines opposing tensions or perspectives.

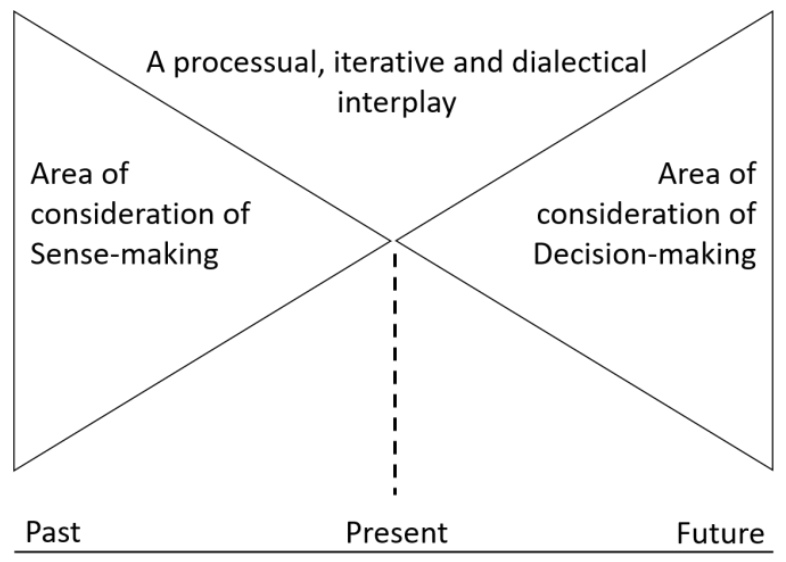

Figure 3. A processual, iterative and dialectical interplay.

This processual, iterative and dialectical interplay, is close to our re-conceptualization of Entrepreneurial Orientation as a process aimed at new opportunity designing, intimately linked to learning and organizing (Garud et al., 2008; Jelinek et al., 2008; Yoo et al., 2006). This iteration, however, must also include the recursive relationship between entrepreneurial agency and structure (Figure 4), inspired by Giddens (1984; 1991).

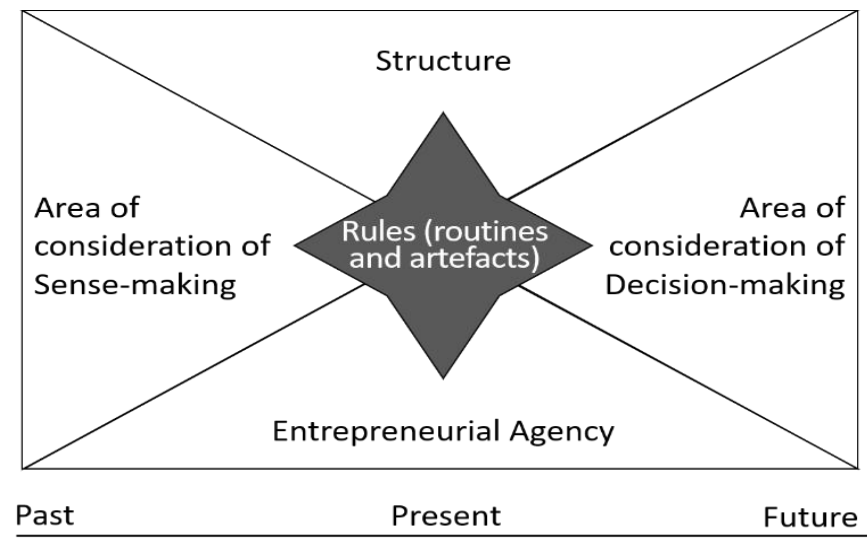

Figure 4. Our tentative framework.

Taking a cue from previous arguments, we can conceive structure as a bundle of 'general' rules and resources that affect entrepreneurial agency in a situated context, historically and culturally characterized. Inspired by Reynaud (2005) mentioned above, we argue that the relationship between structure and entrepreneurial agency is given by 'general' rules (rather than scripts) as arrangements awaiting enactment and interpretation, and routines as rules already interpreted, although modifiable in a contextualized way. 
Routines require effort (Reynaud, 2005; Zamarian, 2011), demanding that individuals make sense of the rules that might be available to them (Parmigiani and Howard-Grenville, 2011:437) or modified/invented.

Besides, routines and artifacts are not only the result of iterations of decision and action, but are elements that agents include and consider within the decision-making process itself (Zamarian, 2011), as above-mentioned.

Our theoretical framework is general enough to be used at an individual or a collective level. At the same time, it is sufficiently characterized from an entrepreneurial point of view thanks to the explicit entrepreneurial nature of agency, which is oriented to the specific purpose of designing new entrepreneurial opportunities. This purpose is also what allows Entrepreneurial Orientation to link entrepreneuring to organizing. Indeed, a new venture, a new entry, extends the action of the entrepreneur beyond the development of good or service concepts, including the action streams of designing and organizing a business opportunity (George and Bock, 2011:99). This does not mean that Entrepreneurial Orientation exhausts the complexity of entrepreneurship, but that Entrepreneurial Orientation, as an essential element, has a process nature itself, which is more coherent with entrepreneuring and organizing.

\subsection{Re-conceptualization of Entrepreneurial Orientation}

Our re-conceptualization of Entrepreneurial Orientation and our framework follow a temporally-oriented "spiral path", in the sense that every development is always structured on what existed before, but also allows the emergence of the new and unfamiliar. Thus, it is important to emphasize that what existed before will already be changed, a little or a lot, after every iteration: uncertainty is not only an unavoidable aspect but a constitutive condition of entrepreneuring, organizing and designing.

Therefore, we re-conceptualize Entrepreneurial Orientation as follows: Entrepreneurial Orientation is a process that captures aspects of decision-making and sense-making, and which emphasizes the role of routines and artifacts as a recursive interplay between structure and entrepreneurial agency. It reflects the "How" rather than the "What" or the "How much". It is entrepreneurial because it is oriented towards the designing of business opportunities and it is intimately linked to learning and organizing in an uncertain and often unpredictable context.

\subsection{Implications and contributions}

As argued by Hjorth et al. (2015), 'the time is right to revert from the conventional question of what (strategic) management studies can do for research on entrepreneurship and instead to consider what entrepreneurship studies can learn from organization studies, and vice versa' (pp. 599-611). We believe that Entrepreneurial Orientation, understood as a process and supported by our theoretical underpinning, can be a fertile starting ground for this dialogue. Using our framework, scholars could explore further by studying, understanding and testing relationships, unifying a highly disparate research domain centered on innovations in uncertain contexts and (proto) organizational projects. Perhaps, more importantly, our work offers theoretical support to move away from:

- A concept of Entrepreneurial Orientation as a mere attitude or a set of personal traits of privileged and heroic individuals.

- A drift (although very attractive), mostly focused on "How much", supported by an increasingly sophisticated use of quantitative measurements, at the cost of conceiving of Entrepreneurial Orientation as an undisputed explanation.

The spirit of Entrepreneurial Orientation is not mere repetition or redoing, but renewing, breaking the rules, seeing the world with different eyes: in short, developing original and alternative representations of the world and then acting. Here is the root of the problem: going to the source, to the representation(s) for decisions and actions. Given the role played by routines and cognitive artifacts in problem-solving and in the representation for action, we propose the following (not exhaustive) issues to explore through further research:

- How might the representation of the space of problems and solutions aimed at opportunity innovation be broadened or drastically changed? Can this be learned, taught, transferred? How?

- How might the processes of change, even radical, of organizational routines aimed at continuous innovation be fostered, not only at firm level but also at entrepreneurial and managerial levels, without distorting their precious organizational role of situated "memory"?

- How might cognitive artifacts as devices, physical or logical, support problem-solving, for example by balancing human agency and artificial intelligence/agency?

We are aware of the limits of our work. It is theoretical in nature and needs further development and empirical study. However, we argue that it represents a fruitful and innovative bridge between research fields that have been isolated for too long. Indeed, the possibilities of bringing together the two traditions of decision-making and sense-making as an interplay combined with Structuration Theory is an exciting "third way": a new horizon for organizational and managerial research, practice and learning. 


\subsection{Main references}

Acs, Z. J.,\&Audretsch, D. B. (2010). Handbook on Entrepreneurship Research: An Interdisciplinary Survey and Introduction. New York: Springer.

Anderson, A. R., Drakopoulou, D. S.,\& Jack S. L. (2012). Entrepreneurship as connecting: some implications for theorising and practice. Management Decision, 50(5), 958-971.

Barley, S. R. (1986). Technology as an occasion for structuring: Evidence from observations of CT scanners and the social order of radiology departments. Administrative science quarterly, 31(1), 78-108.

Barley, S. R.,\& Tolbert P. S. (1997). Institutionalization and structuration: Studying the links between action and institution. Organization studies, 18(1), 93-117.

Baron, R. A. (2014). Thinking about cognition and its central role in entrepreneurship: Confessions of a 'reformedbehaviorist'. In: Mitchell, J. R., Mitchell, R. K.,\& Randolph-Seng, B. (eds) Handbook of entrepreneurial Cognition. Cheltenham, UK - Northampton, MA: Edward Elgar, 61-85.

Benson, J. K. (1977). Organizations: A dialectical view. Administrative science quarterly, 22(1), 1-21.

Berti, M. (2013). Powerful thinking in business education: Rhetoric and practices in the innovation of UTS Business School. PhD Thesis, UTS Business School, Sydney, NSW, Australia.

Bhuian, S. N., Menguc, B.,\& Bell S.J. (2005). Just entrepreneurial enough: the moderating effect of entrepreneurship on the relationship between market orientation and performance. Journal of business research, 58(1), 9-17.

Boland, R. J. (2008). Decision making and sensemaking. In: Burstein, F.,\&Holsapple, C. W.(eds) Handbook on Decision Support Systems 1. Berlin, Heidelberg: Springer, 55-63.

Buchanan, R. (1992). Wicked problems in design thinking. Design Issues, 8(2), 5-21.

Burgelman, R.A. (1983). A process model of internal corporate venturing in the diversified major firm. Administrative science quarterly, 28(2), 223-244.

Bygrave, W. D. (2007). The entrepreneurship paradigm (I) revisited. In: Neergaard, H.,\&Ulhøi, J. P. (eds),Handbook of qualitative research methods in entrepreneurship. Cheltenham, UK - Northampton, MA: Edward Elgar, 17-48.

Chiasson, M.,\& Saunders, C. (2005). Reconciling diverse approaches to opportunity research using the structuration theory. Journal of business venturing, 20(6), 747-767.

Cope, J. (2005). Toward a dynamic learning perspective of entrepreneurship. Entrepreneurship theory and practice, 29(4), 373-397.

Covin, J. G.,\& Lumpkin, G. T. (2011). Entrepreneurial orientation theory and research: Reflections on a needed construct. Entrepreneurship theory and practice, 35(5), 855-872.

Covin, J. G.,\& Miller, D. (2014). International entrepreneurial orientation: Conceptual considerations, research themes, measurement issues, and future research directions. Entrepreneurship Theory and Practice, 38(1), 11-44.

Covin, J. G.,\& Wales, W. J. (2012). The measurement of entrepreneurial orientation. Entrepreneurship theory and practice, 36(4), 677-702.

Czarniawska, B. (2004). Management as designing for an action net. In: Boland, R. J.,\& Collopy, F. (eds), Managing as designing. Stanford, CA: Stanford University Press, 102-105.

Duening, T. N. (2010). Five minds for the entrepreneurial future: Cognitive skills as the intellectual foundation for next generation entrepreneurship curricula. The Journal of entrepreneurship, 19(1), 1-22.

Dunbar, R. L.,\& Starbuck, W. H. (2006). Learning to design organizations and learning from designing them. Organization Science, 17(2), 171-178.

Gartner, W. B. (1988). "Who is an entrepreneur?" is the wrong question. American journal of small business, 12(4), 11-32.

Garud, R.,\&Karnøe, P. (2003). Bricolage versus breakthrough: distributed and embedded agency in technology entrepreneurship. Research policy, 32(2), 277-300.

Garud, R., Jain, S.,\& Tuertscher, P. (2008). Incomplete by design and designing for incompleteness. Organization studies, 29(3), 351-371.

George, B. A.,\& Marino, L. (2011). The epistemology of entrepreneurial orientation: Conceptual formation, modeling, and operationalization. Entrepreneurship Theory and Practice, 35(5), 989-1024.

George, G.,\& Bock, A. J. (2011). The business model in practice and its implications for entrepreneurship research. Entrepreneurship theory and practice, 35(1), 83-111.

Giddens, A. (1984). The Constitution of Society: Outline of the Theory of Structuration. Berkeley, CA: University of California Press.

Giddens, A. (1991). Modernity and self-identity: Self and society in the late modern age. Stanford, CA: Stanford University Press. 
Goss, D., Jones, R., Betta, M.,\& Latham, J. (2011). Power as practice: A micro-sociological analysis of the dynamics of emancipatory entrepreneurship. Organization Studies, 32(2), 211-229.

Greenberger, D. B.,\& Sexton, D. L. (1988). An interactive model of new venture initiation. Journal of Small Business Management, 26(3), 1-7.

Helfat, C. E.,\& Martin, J. A. (2015). Dynamic managerial capabilities: Review and assessment of managerial impact on strategic change. Journal of Management, 41(5), 1281-1312.

Hernes, T. (2014). A process theory of organization. Oxford: Oxford University Press.

Hjorth, D. (2013). Public entrepreneurship: Desiring social change, creating sociality. Entrepreneurship \& Regional Development, 25(1-2), 34-51.

Hjorth, D.,\&Steyaert, C. (2004). Narrative and discursive approaches in entrepreneurship: a second movements in entrepreneurship book. Cheltenham, UK - Northampton, MA: Edward Elgar.

Hjorth, D., Holt, R.,\&Steyaert, C. (2015). Entrepreneurship and process studies. International Small Business Journal, 33(6), 599-611.

Ireland, R. D., Hitt, M. A.,\&Sirmon, D. G. (2003). A model of strategic entrepreneurship: The construct and its dimensions. Journal of management, 29(6), 963-989.

Jelinek, M., Romme, A. G. L.,\& Boland, R. J. (2008). Introduction to the special issue: Organization studies as a science for design: Creating collaborative artifacts and research. Organization Studies, 29(3), 317-329.

Johannisson, B. (2011). Towards a practice theory of entrepreneuring. Small business economics, 36(2), 135-150.

Katz, J.,\& Gartner, W. B. (1988). Properties of emerging organizations. Academy of management review 13(3), 429441.

Kirzner, I. M. (1997). Entrepreneurial discovery and the competitive market process: An Austrian approach. Journal of economic Literature, 35(1), 60-85.

Kreiser, P. M. (2011). Entrepreneurial orientation and organizational learning: The impact of network range and network closure. Entrepreneurship Theory and Practice, 35(5), 1025-1050.

Krueger, N. F.,\&Carsrud, A. L. (1993). Entrepreneurial intentions: applying the theory of planned behaviour. Entrepreneurship \& Regional Development, 5(4), 315-330.

Low, M. B.,\& MacMillan, I. C. (1988). Entrepreneurship: Past research and future challenges. Journal of management, 14(2), 139-161.

Lumpkin, G. T.,\& Dess, G. G. (1996). Clarifying the entrepreneurial orientation construct and linking it to performance. Academy of management Review, 21(1), 135-172.

Lumpkin, G. T.,\& Dess, G. G. (2001). Linking two dimensions of entrepreneurial orientation to firm performance: The moderating role of environment and industry life cycle. Journal of business venturing, 16(5), 429-451.

Miller, D. (1983). The correlates of entrepreneurship in three types of firms. Management science, 29(7), 770-791.

Miller, D. (2011). Miller (1983) Revisited: A Reflection on EO Research and Some Suggestions for the Future. Entrepreneurship Theory and Practice,35(5), 873-894.

Moroz, P. W.,\&Hindle, K. (2012). Entrepreneurship as a process: Toward harmonizing multiple perspectives. Entrepreneurship Theory and Practice, 36(4), 781-818.

Nielsen, S. L., Klyver, K., Evald, M. R.,\&Bager, T. (2017). Entrepreneurship in theory and practice: Paradoxes in Play. Cheltenham, UK - Northampton, MA: Edward Elgar, 201-223.

Parmigiani, A.,\& Howard-Grenville, J. (2011). Routines revisited: Exploring the capabilities and practice perspectives. Academy of Management Annals, 5(1), 413-453.

Rauch, A., Wiklund, J., Lumpkin, G.T.,\&Frese, M. (2009). Entrepreneurial orientation and business performance: An assessment of past research and suggestions for the future. Entrepreneurship theory and practice, 33(3), 761787.

Reynaud, B. (2005). The void at the heart of rules: routines in the context of rule-following. The case of the Paris Metro Workshop. Industrial and Corporate Change, 14(5), 847-871.

Sarasvathy, S. D. (2001). Causation and effectuation: Toward a theoretical shift from economic inevitability to entrepreneurial contingency. Academy of management Review, 26(2), 243-263.

Sarasvathy, S. D. (2003).Entrepreneurship as a science of the artificial. Journal of Economic Psychology, 24(2), 203220.

Simon, H. A. (1957). Models of Man. New York, NY: Wiley.

Simon, H. A. (1969). The Sciences of the Artificial. Cambridge, MA: MIT Press.

Sosna, M., Trevinyo-Rodríguez, R. N.,\&Velamuri, S. R. (2010). Business model innovation through trial-and-error learning: The Naturhouse case. Long range planning, 43(2-3), 383-407.

Steyaert, C. (2007). 'Entrepreneuring' as a conceptual attractor? A review of process theories in 20 years of entrepreneurship studies. Entrepreneurship and regional development, 19(6), 453-477. 
Trimi, S.,\&Berbegal-Mirabent, J. (2012). Business model innovation in entrepreneurship. International Entrepreneurship and Management Journal, 8(4), 449-465.

Ucbasaran, D., Westhead, P.,\& Wright, M. (2001). The focus of entrepreneurial research: contextual and process issues. Entrepreneurship theory and practice, 25(4), 57-80.

Verduyn, K. (2015).Entrepreneuring and process: A Lefebvrian perspective. International Small Business Journal, 33(6), 638-648.

Weick, K. E. (1979). The Social Psychology of Organizing. New York, NY: Newbery Award Records.

Weick, K. E. (1995). Sensemaking in organizations. Thousand Oaks, CA: Sage.

Weick, K. E., Sutcliffe, K. M.,\& Obstfeld, D. (2005). Organizing and the process of sensemaking. Organization science, 16(4), 409-421.

Wiklund, J.,\& Shepherd, D. (2003). Knowledge- based resources, entrepreneurial orientation, and the performance of small and medium- sized businesses. Strategic management journal, 24(13), 1307-1314.

Wiklund, J.,\& Shepherd, D. A. (2011). Where to from here? EO-as-experimentation, failure, and distribution of outcomes. Entrepreneurship Theory and Practice, 35(5), 925-946.

Yoo, Y., Boland, R. J. Jr,\& Lyytinen, K. (2006). From organization design to organization designing. Organization Science, 17(2), 215-229.

Zahra, S. A. (2007). Contextualizing theory building in entrepreneurship research. Journal of Business venturing, 22(3), 443-452.

Zamarian, M. (2011).Artefacts cognitifs et routines organizationnelles. In Maggi, B. (ed) Interpreter l'agir: un défithéorique. Paris: Presses Universitaires de France, 279-296 